\title{
The contribution of sense of place to social-ecological systems research: a review and research agenda
}

\author{
Vanessa A. Masterson ${ }^{1}$, Richard C. Stedman $^{2}$, Johan Enqvist $^{1}, \underline{\text { Maria Tengö }}^{1}, \underline{\text { Matteo Giusti }}^{1}$, Darin Wahl $^{1,3}$ and Uno Svedin $^{1}$
}

\begin{abstract}
To develop and apply goals for future sustainability, we must consider what people care about and what motivates them to engage in solving sustainability issues. Sense of place theory and methods provide a rich source of insights that, like the socialecological systems perspective, assume an interconnected social and biophysical reality. However, these fields of research are only recently beginning to converge, and we see great potential for further engagement. Here, we present an approach and conceptual tools for how the sense of place perspective can contribute to social-ecological systems research. A brief review focuses on two areas where relation to place is particularly relevant: stewardship of ecosystem services, and responses to change in social-ecological systems. Based on the review, we synthesize specific ways in which sense of place may be applied by social-ecological systems researchers to analyze individual and social behaviors. We emphasize the importance of descriptive place meanings and evaluative place attachment as tools to study the patterned variation of sense of place within or among populations or types of places and the implications for resilience and transformative capacity. We conclude by setting out an agenda for future research that takes into account the concerns of resilience thinking such as the effects of dynamic ecology, interactions between temporal and spatial scales, and the interplay of rapid and incremental change on sense of place and place-related behaviors. This future research agenda also includes concerns from the broader sense of place literature such as the importance of structural power relationships on the creation of place meanings and how scaling up a sense of place may influence pro-environmental behavior.
\end{abstract}

Key Words: cognitions; place attachment; place meanings; resilience thinking; responses to change; sense of place; social-ecological systems; stewardship; transformation

\section{INTRODUCTION}

In recent years, there has been increased interest in planetary-level initiatives such as the newly launched Sustainable Development Goals (United Nations 2014). The adoption of these sustainability goals reflects a growing realization that environmental problems require not only an understanding of ecological systems, but also of integrated social-ecological systems (SES). To develop and pursue these ambitious goals, we must consider what people care about and what motivates them to engage in solving sustainability issues. It is necessary to understand the human feedback mechanisms in the dynamics of SES, and how such responses are underpinned by values, cognitions, and perceptions of human relationships with nature (Raymond et al. 2013, von Heland and Folke 2014, Chan et al. 2016).

The research that informs such sustainability goals includes broadly the field of sustainability science and lenses such as resilience thinking and the SES perspective (Berkes and Folke 1998, Folke 2006). The SES perspective builds on interdisciplinary research linking ecology to economy and political science (Berkes and Folke 1998, Folke 2006, Liu et al. 2007). Cognitions have been relatively neglected and undertheorized in SES research (Jones et al. 2016), but scholars are asking questions about the deeper, slower variables in social systems such as identity, core values, and worldviews (Folke et al. 2010, Berkes and Ross 2013) that guide and constrain human actions (Adger et al. 2009). The need to understand and assess more systematically these variables requires closer engagement with social sciences and humanities (Daniel et al. 2012, Brown et al. 2013, Pröpper and Haupts 2014).
One field of research that directly addresses values and behavior, and which also shares the ontology of an interconnected social and natural world, is that of sense of place.

Invoking notions of sense of place is already helping to improve analysis in SES research. However, sense of place is often not operationalized in a way that leverages the richer theoretical and empirical tradition within sense of place literature, and this sometimes contributes to conceptual confusion or misuse. More than just acknowledging sense of place as a relevant concept, we emphasize the role of sense of place as a field of research with conceptual and methodological tools that have great potential to inform emerging SES research. Given that sense of place research, in some instances, has lacked construct clarity and has used conflicting definitions (Jorgensen and Stedman 2001), we present a user-friendly approach for SES scholars. We select and define a specific set of core sense of place constructs, including place attachment and place meaning, and briefly lay out the ontoepistemological assumptions that we think make this approach compatible with SES analyses.

We review how sense of place has been employed within two key areas of enquiry in SES research and resilience thinking: stewardship of ecosystem services and responses to change. These are areas where SES scholars have started to implicitly or explicitly invoke relation to place: sense of place is considered as a motivation for stewardship and actions to care for the environment; it is also presented as a cognitive and emotional variable that mediates how people respond to social-ecological change. We point out where the engagement has been incomplete

\footnotetext{
${ }^{1}$ Stockholm Resilience Centre, Stockholm University, ${ }^{2}$ Human Dimensions Research Unit, Department of Natural Resources, Cornell University,
} ${ }^{3}$ Portland State University, Portland, Oregon (current) 
or imprecise and highlight how this may have generated some contradictory and incompatible findings. We then synthesize a set of specific applications in which a sense of place perspective would help advance the tools and approaches of SES researchers. In addition, we highlight future research questions that arise from considering the broader interests of both research fields.

\section{AN APPROACH TO SENSE OF PLACE RESEARCH}

Sense of place has a 40-year trajectory of scholarship, and SES research should draw on and respond to this trajectory to make the best use of the theory. We emphasize that there are myriad different methodological approaches that can and have been used to study sense of place (for a useful review see Trentleman 2009; for a spirited debate see Stedman and Beckley 2007, Williams and Patterson 2007). The sense of place literature includes multiple constructs and conflicting definitions, leading some to describe the scholarship as confusing, contradictory, or messy (e.g., Hidalgo and Hernández 2001, Jorgensen and Stedman 2001, Pretty et al. 2003). In response, and at risk of oversimplification, we sort place scholarship into two main domains. The first, the phenomenological domain, includes approaches that emphasize the particular character of lived experience in place. Qualitative methodologies are emphasized that avoid "a priori theory and concepts, hypotheses, predetermined methodological procedures [and] statistical measures of correlation..." (Seamon 2000:163). Trentleman (2009) notes that foundational place writings are often in this vein.

The second domain embraces cause and effect relationships between concepts, prediction, hypothesis testing, and where appropriate, generalization (e.g., see Shamai 1991, Lalli 1992, Jorgensen and Stedman 2001). This approach separates core constructs into different spheres such as cognition and emotion, and emphasizes the individual as the unit of analysis. Our paper employs the latter approach to sense of place as potentially readily embedded within the systems perspective that characterizes resilience thinking and studies of SES. We emphasize that these two domains ought not to be seen as oppositional, but rather, complementary, each providing its own set of insights that can be conjoined (see Stedman and Beckley 2007).

We have presented our approach and its specific relevance for research that assumes an interconnected social and biophysical reality. Next, we clarify several key concepts that are well-reflected within our approach and which are readily linked to the SES framework (see Fig. 1). We then specify some ontoepistemological assumptions that underlie our approach and shape how the concepts are applied.

\section{An introduction to key terms}

Sense of place is described by Tuan (1977) as the meanings and attachment to a setting held by an individual or group. As such, it is often viewed as the most encompassing core construct within associated research (e.g., Shamai 1991, Kaltenborn 1998). Crucially, our approach to sense of place analysis emphasizes both attachment and meanings, although these concepts are sometimes conflated and greater analytical emphasis is given to place attachment than to place meanings (Stedman 2008).

Place attachment is an emotional bond, usually positive, between individuals or groups and their environment (Altman and Low 1992). As such, it is fundamentally evaluative (i.e., good vs. bad, important vs. unimportant). Place attachment is sometimes conceived as having two subdomains: dependence and identity. Place dependence (Stokols and Shumaker 1981) conveys an instrumental connection between people and place, conceived and measured as the ability of a setting to facilitate goal achievement and to satisfy important needs (see also Tidball and Stedman 2013 for reflections on the positive nature of dependence). It has been measured through survey items such as, "This is the best place to do the things I enjoy" (Jorgensen and Stedman 2001). In comparison, place identity is defined by Proshansky (1978:155) as "those dimensions of self that define the individual's personal identity in relation to the physical environment." Place elements thus become partial answers to the symbolic question of "Who am I?" and play a part in the formation of the self (Sack 1997). Place identity is an evaluative concept and should not be confused with the structures and functions that characterize a particular setting (what resilience literature refers to as system identity; Folke et al. 2010) or with what is sometimes called place character (e.g., Lyon 2014). A person's place identity has been measured through survey items such as, "[This place] really reflects the kind of person I am" (e.g., Jorgensen and Stedman 2001). Although dependence and identity can be articulated as distinct conceptual domains, research results are mixed: some scholars (Moore and Graefe 1994) find these to be distinct components of attachment, whereas others (e.g., Stedman 2002) find that they conjoin into a common domain.

Fig. 1. The relationships among key sense of place concepts.

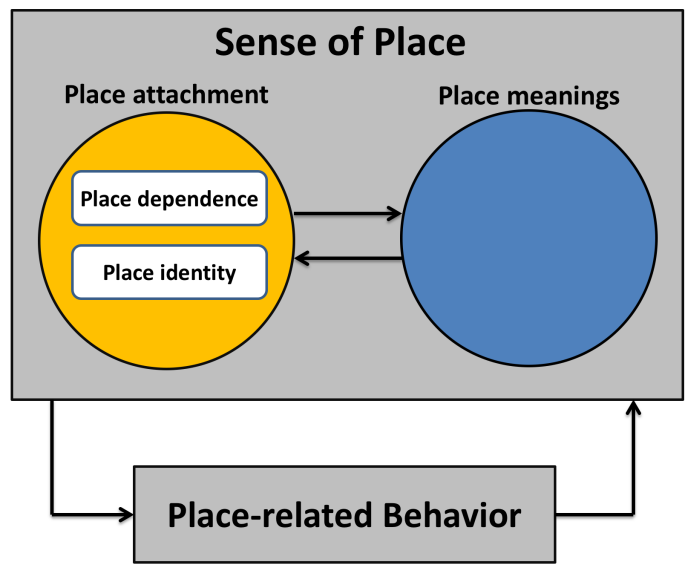

Stedman (2008) argues that the relative neglect of place meaning in sense of place research has led to some serious issues in sense of place research and practice, such as assuming that all people who have strong attachment will mobilize to protect their place from a particular threat. Meanings stand in contrast to attachment in that they are descriptive statements (cognitions, in social psychology terms) about what a place is, what it is like, and the kinds of images it conveys (Manzo 2005, Brehm et al. 2013, Jacquet and Stedman 2013). We can think of them simply as a series of adjectives, i.e., answers to what kind of a place a setting is: polluted, lonely, warm. A second type of meaning is a little less descriptive and a little more symbolic or interpretive, i.e., what, symbolically, does a place mean: Home? Escape? Third, place 
meanings can be considered as place character (Lyon 2014): a given setting can be a farmscape, a tourist place, or a wilderness, for example.

\section{Key assumptions of our sense of place approach}

Here, we explain how our sense of place approach explores a reality with interconnected social and biophysical components. We see the assumptions we describe next as compatible with the SES perspective and therefore important for forging connections between the two research fields.

1. Sense of place forms through experience, although this experience is not solely individualistic, but also social. A central question in sense of place research involves how sense of place is formed. Early sense of place thinkers (e.g., Relph 1976, Tuan 1977) posit that sense of place is formed through freely chosen direct encounter with landscape; these encounters help to form highly personalized place meanings. Much subsequent scholarship has taken this approach. Although useful, this emphasis has probably impeded the integration of sense of place and SES analyses. Our approach recognizes that sense of place may also be formed through social experiences. This social nature of experience is expressed in several ways. First, experiences differ in systematic, predictable ways based on roles that are socially produced and have socially derived expectations associated with them: one encounters a landscape through his or her role as (for example) a hunter, a real estate developer, or a botanist. The meanings are based, at least in part, on the social expectations associated with each of these roles. A second way in which meanings are fundamentally social rather than just individually formed is based on power relations that affect interpretation and meaning making. Social actors are taught, e.g., through education programs (Kudryavtsev et al. 2012) and interpretation (Rickard and Stedman 2015), about what is important or normative about a place, rather than creating these meanings on their own. Power exerts itself in a subtler way as well: even our experiences are not freely chosen, but are influenced by the current configuration of the landscape (Pred 1984, Zukin 1991, Stokowski 2002). Power establishes rules that manage the landscape and guide meanings. Institutions "create" the environment (Freudenburg et al. 1995) by setting regulations and upholding cultural norms that promote some activities and meanings over others.

2. Sense of place emerges from human interactions with the biophysical environment. Lewicka (2011:213) notes, "For many years, interest in social dimensions of place attachment has been stronger than interest in its physical dimensions." Sense of place has been viewed mostly as a social construction, a product of shared behavioral and cultural processes, rather than the result of perceptual and cognitive processes rooted in physical characteristics of settings (e.g., Greider and Garkovich 1994). However, some authors suggest that we can think of the material environment as contributing to sense of place through direct and indirect causal mechanisms: (1) directly, as the raw material for meanings inferred directly from the landscape: it is easier, for example, to distill wilderness meanings from a landscape with old-growth trees and clean water than from a landscape polluted by human use; (2) indirectly, by enabling or constraining experiences that contribute to meanings. One cannot catch fish (and create meanings such as good fishing places) where no fish exist, e.g., if the water has become polluted or too warm. For an example, see Stedman (2003a) and Stedman and Hammer (2006), who quantitatively assessed the relationship between the number of houses on the shoreline of lakes and meanings, attachment, and concern about water quality. Therefore, we view sense of place as an emergent property of a socialbiophysical interaction, although so far, sense of place research has had a limited appreciation of the role of nature and ecology in forming place (but see, e.g., Stedman and Ingalls (2014), who engage the intersection of topophilia and biophilia as mutually constitutive).

3. Place meanings and attachment are subjective, but they vary systematically. Although each person's sense of place is fundamentally unique, this variation is patterned, rather than random, where different types of people, experiences, and environments will lead to systematic differences in meanings, attachment, and behavior. The subjectivity of meanings is crucial for engaging transformation and stewardship, and sense of place tools enable researchers to ask comparative questions that examine variation. Sources of variation (i.e., based on characteristics of people or place) are important to understand to connect sense of place to systems perspectives (Stedman 2016). This is also useful for relating subjective meanings and their variation to systemlevel effects.

4. Patterned relationships with place help to predict specific types of behavior. Sense of place has been shown to be a powerful predictor of attitudes toward potential changes and behavioral intentions, both reactive and proactive (Bonaiuto et al. 2002, Devine-Wright 2009). A great deal of the sense of place literature implicitly assumes (or explicitly asserts) that greater place attachment leads to pro-environmental behavior. While the truism that "we fight for the places we are attached to" is generically plausible, the relationship is not so simple. People do not simply engage in places they are attached to; their particular forms of engagement rest on place meanings they hold dear and perceive as threatened (Vorkinn and Riese 2001, Kyle et al. 2004). Because there can be a range of meanings associated with the same place, people respond to change differently depending on how their respective meanings are affected by this change (Stedman $2003 a$, 2008). Our approach to sense of place provides the tools to assess and characterize the relationship between attachment and behavioral intentions and actions. In particular, because place is not the same as environment, not all threats to place meanings are environmental; for instance, attachment to place that symbolizes one's social connections (civic place attachment) has been found not to be correlated with pro-environmental behavior (Scannell and Gifford 2010).

\section{A BRIEF REVIEW OF THE USE OF SENSE OF PLACE IN SOCIAL-ECOLOGICAL SYSTEMS RESEARCH}

Place is increasingly important as an organizational concept in SES studies, building on the experiences of the Millennium 
Ecosystem Assessment and the move toward long-term comparative place-based studies (Carpenter et al. 2009, Wilbanks 2015). Previous engagements with sense of place by SES scholars treat it as a phenomenon relevant to understanding certain socialecological processes. Although this engagement often operates in similar intellectual terrain as sense of place research without necessarily using the same language (i.e., indirect engagement), it has also more directly invoked constructs from sense of place literature such as place attachment or identity.

We next review SES research that engages sense of place both directly and indirectly to demonstrate the relevance of further engagement with sense of place and to identify weaknesses and gaps that can be strengthened by a more rigorous approach to sense of place. The review is organized into two themes in which engagement with sense of place is already taking place and in which we see considerable potential for theory and methods from the field of sense of place research to inform thinking.

\section{Sense of place and stewardship of ecosystem services}

Stewardship generally refers to a responsible management or caretaking, often of natural resources or the environment. The term has been adopted by SES scholars to describe more specifically an active shaping of development trajectories at multiple scales, in a way that manages for uncertainty and threshold effects, and the normative goals of building ecological resilience and improving human well-being (Chapin et al. 2011, Folke et al. 2011). We review three ways in which sense of place is drawn on to understand stewardship.

\section{People-place relations can strengthen protective norms}

Among the most straightforward arguments linking stewardship to sense of place is as a "motivation for long-term stewardship" (Chapin and Knapp 2015:38) or in other ways supporting proenvironmental or pro-conservation behavior (for reviews, see Meyfroidt 2013, Gifford 2014, and Zylstra et al. 2014). This argument draws on early explorations of how to manage SES that invoke sense of place as a complex concept that influences peoples' perceptions and actions (Davidson-Hunt and Berkes 2003, Andersson et al. 2007), and the role of relationships to place and nature for stewardship actions, including local and traditional ecological knowledge, as embedded in institutions for stewardship (Folke et al. 2003, 2005). This is expressed explicitly by Chapin and Knapp (2015:39), who argue that, "capitaliz[ing] on the attachment that people feel to particular places [can] provide a foundation for stewardship strategies." Sense of place is seen as a prerequisite condition for residents to notice degradation and trigger action through public concern (Chapin et al. 2012). There is also growing interest in sense of place from related fields such as conservation ecology, which has begun to explore place attachment as motivating conservation behavior (e.g., Farmer et al. 2011, Raymond et al. 2011, Larson et al. 2013).

Further, it has been argued that contested senses of place can be an obstacle for stewardship (Chapin and Knapp 2015) and, alternatively, that consensus regarding place meanings can contribute to community cohesion and sustainability (Chapin et al. 2012). Scholars studying civic engagement in stewardship groups have identified tensions between how different members' relations to a place are articulated (Ernstson and Sörlin 2009) and have started to explore the consequences of such heterogeneity within groups (Enqvist et al. 2014). While this is a good starting point, these attempts have yet to engage fully and rigorously with concepts of sense of place such as place meaning and how it influences people's behavioral intentions.

\section{Sense of place in assessment of ecosystem management}

Sense of place has been employed in a range of ways in relation to assessments of ecosystem services and their management: for assessment of preferences in planning, as an indicator of cultural ecosystem services, and as a constituent of well-being as derived from ecosystems. First, sense of place has been applied as a tool for assessing values and preferences in ecosystem assessments (Martín-López et al. 2012, Plieninger et al. 2013), for example, to identify human-valued priority areas for environmental conservation and management (Raymond et al. 2009) and to inform land-use planning (Brown and Raymond 2007).

Second, ecosystem assessments have explicitly incorporated sense of place as an ecosystem service in its own right (Millennium Ecosystem Assessment 2005, Hausman et al. 2016) and as a quantitative indicator (see Hernández-Morcillo et al. 2013). In particular, it has been used in the realm of cultural ecosystem services, which include intangible values that are difficult to measure (Butler and Oluoch-Kosura 2006, Chan et al. 2012), partly because of the subjective and place-based variation of cultural ecosystem services (e.g., Daniel et al. 2012, Milcu et al. 2013). Some of these challenges may be resolved through more systematic engagement with sense of place as an indicator of cultural ecosystem services.

Third, sense of place has been theorized as a constituent of wellbeing, including well-being contingent upon ecosystem services (Summers et al. 2012, Russell et al. 2013). However, there has been insufficient attention to understanding well-being as co-created by people and ecosystems (Smith et al. 2013), as well as incorporating the subjectivity of well-being in this context (Breslow et al. 2016). It is notoriously difficult to assess human well-being in a way that captures fine-grained variations within or among groups of people in the same place (Raudsepp-Hearne et al. 2010, Daw et al. 2011, Russell et al. 2012). Applying sense of place tools as an indicator of subjective well-being could contribute to meeting these challenges.

Stewardship practices and knowledge are embedded in place Place-based approaches to ecosystem assessments are beneficial for clarifying local contexts, values, and priorities (Potschin and Haines-Young 2013). Place has been implicitly invoked in studies linking ecosystem resilience to community well-being (Berkes and Folke 1998), especially in the coevolution of local and traditional ecological knowledge, adaptive institutions, and responding to changes in nature and landscape dynamics (Berkes et al. 2000, Olsson and Folke 2001, Tengö and von Heland 2011).

Chapin and Knapp (2015) argue that stewardship can be fostered by the place attachments produced through repeated personal experiences filtered through identity and social context. Research focusing on stewardship in urban SES has argued that a stronger sense of place is associated not only with stronger protective norms but also more local ecological knowledge (Andersson et al. 2007). Barthel et al. (2013:1149) argue that relation to place matters for "stewardship memory" because "biophysical elements, including species, landscape features, written accounts and artifacts [...] structure management practices" and thereby 
provide a guide for stewardship that is better adapted to local conditions. Learning through experience that is embedded in local, place-based institutions is emphasized in this context, as well as the role of emotional and cultural connections to place (e.g., Berkes et al. 2003, von Heland and Folke 2014). Recent work also emphasizes that the emotional attachment to place can serve as a bridge between ecosystem functioning and stakeholders' engagement in environmental stewardship (Andersson et al. 2015). So far, the use of sense of place as a concept in this literature has been vague and ad hoc and stands to gain considerably from a more systematic empirical engagement with sense of place literature.

\section{Sense of place and responding to change in social-ecological systems}

Another important area within SES research concerns the capacity of individuals, communities, and institutions to respond and adapt to social and ecological change (Berkes et al. 2003, Walker et al. 2004, Westley et al. 2011) or to transform fundamentally the nature of SES toward more sustainable trajectories (Walker et al. 2004, Chapin et al 2010). Transformative change often involves shifts in perception and meaning (Folke et al. 2010). Disturbances to SES such as flooding, industry closure, or climate change can affect the character of a place through a change to the material and social aspects of place, and consequently, can affect the symbolic meanings that residents hold dear, causing psychological and emotional distress (Albrecht et al. 2007, Jacquet and Stedman 2014). Therefore, sense of place has been studied as a cognitiveemotional factor that may affect how individuals and communities engage in change processes (Adger et al. 2009, 2013, Clayton et al. 2015 ) by adapting practices to new conditions, relocating to another place, or shifting economic strategies. We review two main areas of engagement with sense of place and its influence on responses to change.

\section{Strong place attachment may support adaptation to change}

SES research has begun to point to sense of place as an important foundation of community resilience (e.g., Berkes and Ross 2013). Studies show that place attachment may support adaptation when livelihoods are threatened by changes such as declining agricultural viability in the face of climate change (Marshall et al. 2012, Eakin et al. 2016), declining populations and services (Amundsen 2013), increased risk of flooding (Quinn 2014), or gradual industry closure (Sampson and Goodrich 2005, Lyon 2014). By adapting to these changes, community structure and character of place can be retained, which may foster social resilience (Sampson and Goodrich 2005, Lyon 2014). Specifically, Marshall et al. (2012) suggest that place attachment enhances adaptive capacity, proposing that social capital, local knowledge, and reciprocal networks facilitate adaptation to incremental social-ecological change. Eakin et al. (2016) show that for farmers in Arizona, USA, it is the commitment to community associated with place attachment that contributes to adaptive learning to maintain viability as farmers.

Resilience thinking has improved the understanding of adaptation as the ability to change in order to remain in a current state. However, to understand better how emotion and perception affect adaptation requires better attention to what people are attached to, as well as how the specific changes may influence individual and group identity. For example, adaptations to climate change may be supported by an understanding of the threat that climate change poses to place identity (Adger et al. 2011, Fresque-Baxter and Armitage 2012), e.g., farming that has remained in a place for several generations. Similarly, adaptation strategies can also be resisted by certain groups if the required adaptations threaten such identities. Without a thorough understanding of these dimensions of sense of place, studies may not be able to assess accurately adaptive capacity in communities facing novel circumstances.

\section{Place attachment as a barrier for transformative change}

Place attachment may also be a barrier to navigating change when incremental responses are insufficient and more fundamental change is required to break feedbacks that lead to degradation of ecosystems and well-being. For example, strong place attachment is negatively related to peanut farmers' and cattle grazers' willingness to incorporate transformative change into their work lives by relocating along with the industry when conditions are no longer tenable (Marshall et al. 2012, Marshall and Stokes 2014). The nature of change is important: if a shift of occupation or location is required, strong place attachment can be a barrier to change. In this way, strong attachment constrains migration away from areas of high exposure to, for example, climate change effects (Adger et al. 2013).

Other studies have begun to assess the role of sense of place on transformative change within a place. Marshall et al. (2016) engaged agricultural producers who may be subject to untenable agricultural conditions because of predicted climate change effects. They assessed transformative capacity in terms of the willingness to change land-use production and diversify livelihoods and found that strong place attachment was correlated with low transformative capacity. In contrast, preliminary work points to the importance of place meanings for successful transformation: Lyon (2014) argues that the culturally inherited character of a place can function as an asset for the community during a successful transformation process, and Chapin et al. (2012) point to the importance of shared place meanings in building consensus and collective action for transformation.

The preceding paragraphs show that different operationalizations of the concept of transformation can produce discrepancy in findings. Some of these discrepancies can be explained by inconsistent uses of sense of place measures. There is also a need to clarify the scale at which attachment to place is studied (e.g., local, regional) and to relate this to the scale at which transformation is occurring.

\section{APPLICATIONS AND FUTURE RESEARCH}

Sense of place research can contribute to SES research in fundamental ways: broadly speaking, sense of place can be both a driver and an outcome of social-ecological processes. It is a social-ecological linkage that can constrain and enable change. Sense of place is an emergent property of individuals and places that matters for better stewardship and is an indicator of human well-being. Our targeted review of sense of place literature, as well as how SES scholars have begun to engage with the concept, demonstrates that there is considerable potential for bringing more rigor to research questions already being asked within SES studies and for developing new research questions in this realm. 
Based on the gaps identified here, we discuss four ways in which our approach to sense of place can be applied by scholars studying SES. We then identify future research areas where further engagement across sense of place scholarship and SES research holds potential. We note that scholars have tended to study sense of place as motivating stewardship practices or as a cognitive influence underpinning human responses to change, i.e., in separate themes. However, stewardship of ecosystems requires a capacity to deal with uncertainty and complexity and to navigate fundamental shifts or transformations (Chapin et al. 2011), so there is great potential for combination of the two themes, and hence, we discuss these together here.

Applications of sense of place in social-ecological systems studies In the following, we synthesize and discuss areas that could be informed by existing sense of place research. In other words, what can sense of place do for SES scholarship?

\section{Identify what underpins protective and restorative actions}

Sense of place literature provides theory and tools for a more nuanced understanding of the root of pro-environmental actions. First, research on place attachment has shown that place attachment can indeed contribute to protective and restorative stewardship actions in dynamic SES. For example, disasters that trigger human affinity for nature and meaningful places can also give rise to actions to rebuild environments and restore ecological function (Tidball 2012). Place attachment provides an evaluative measure (e.g., Williams and Roggenbuck 1989, Stedman 2002) for empirical studies of the role of sense of place in motivating or discouraging stewardship actions, which could expand the work of, for example, Andersson et al. (2007) and Barthel et al. (2010).

Second, strong attachment is associated with care and action (Vorkinn and Riese 2001), but this does not necessarily predict what type of action is supported (Huber and Arnberge 2016). Attachment is based on meanings: We become attached to a landscape as embodying a certain set of meanings, and it is those meanings we seek to preserve (Stedman 2003a, Devine-Wright 2009). Place meanings and attachment are thus analytically distinct: people who are all strongly attached to a place are not necessarily attached to the same thing because one setting can embody many different sets of meanings, each emphasized by different actors. For example, a small rural town may represent a place of strong community and familiarity, a place of natural beauty with good recreational opportunities, or a "backwards" and stifling place with no economic opportunities. As shown in studies of hypothetical changes in recreational lakes (Stedman $2003 a$ ) as well as industrial wind farm development (Jacquet and Stedman 2013), opposition or support to change is influenced by which meanings are threatened and which are not (Stedman 2008). Debates about the future of a place are thus rarely between people who are attached vs. people who are not, but are rather between holders of different or even oppositional meanings.

Third, because meanings frame what it is that people see as worthy of protection or enhancement, it follows that place meanings underpin individual and collective behavior in stewardship and in responding to change. For example, recruiting volunteers for a wetland nature reserve may be more or less successful depending on whether nearby residents see the area as a birdwatching site or as a place to do water sports.
Map and assess patterns of variation

Another application for SES research comes from the realization that place-related actions and responses are not random (refer to the assumptions set out earlier in this paper). Place attachment and place meanings vary systematically across a population, and this variability can be measured through a range of standardized quantitative tools (e.g., Stedman 2003b) as well as innovative qualitative and mixed methods such as visual methods (e.g., Beckley et al. 2007), mapping (Brown and Raymond 2007), or narrative interviews (Russ et al. 2015). As we noted previously, synthetic understandings of place emerge through conjoining multiple methods, both quantitative and qualitative. For example, community change could be analyzed by exploring how meanings and attachment differ between long-term residents and newcomers and how their responses to social-ecological change may vary (i.e., How do different kinds of people interpret and respond to different kinds of changes such as increased population or pollution?). Analysis can also compare across different types of environments or different political regimes. Researchers can also conduct longitudinal analysis (e.g., Have dominant meanings changed over time?) and analyze the relationships between changes in attachment and meanings to patterns of environmental change (e.g., What sorts of environmental phenomena are perceived and acted toward in what kinds of ways by what kinds of people?). For example, there are indications that local ecological knowledge may be linked to higher place attachment (Andersson et al. 2007, Eakin et al. 2016). Conceptual tools such as place meanings and measures of attachment can be engaged to understand in more detail how senses of place covary with various types of knowledge and practice, for example.

\section{Evaluate how sense of place patterns influence the resilience of a} system

Knowledge about the patterns of how people relate to place can be applied to understand opportunities for collaboration as well as adaptive and transformative capacity as different aspects of social-ecological resilience. For example, place attachment can work as a motivation for farmers to adapt when conditions make earlier activities untenable. However, it can also impede action when more fundamental transformation is required (Marshall et al. 2012) that threatens place identities (Fresque-Baxter and Armitage 2012). Thus, there is great potential for more research to tease out how different types of attachment, including place identity and dependence, matter for capacity to deal with change, further expanding the work of, for example, Marshall et al. (2012, 2014) and Eakin et al. (2016). Additionally, this research will benefit from engaging place meanings. Assessing how external changes (or lack thereof) threaten specific place meanings may generate a deeper understanding of people's attitudes toward a change and their willingness to act (Stedman 2002, Devine-Wright and Howes 2010).

Another application relates to successful collaboration: coexistence of multiple different place meanings may create conflict and disrupt community cohesion and stewardship (Yung et al. 2003, Chapin et al. 2012, Chapin and Knapp 2015). For example, in rural development interventions, rural communities and state actors or nongovernmental organizations may hold different meanings for a particular landscape (e.g., a forest as a threatened and biodiverse wilderness to be protected from human 
use vs. a sacred site for traditional rituals), as shown in a case study in the Eastern Cape, South Africa (Masterson 2016). Failure to understand these differences might disrupt communication between actors or even cause conflict if the meanings are made explicit but not accepted by the other party. Sense of place research offers methods to evaluate the diversity of place meanings that can be associated with the same place by a group of individuals (Stedman 2006, Jacquet and Stedman 2013, Milcu et al. 2014). In contrast, societies that are able to allow and engage multiple place meanings or make use of shared place meanings may be more resilient (Stedman 1999). The meanings can provide different understandings of emerging problems and thereby diversify the knowledge and range of options available for dealing with change; similarly, this diversity can be a source of innovation for transformation toward more desirable pathways of development in SES.

\section{Assess stewardship outcomes and priorities}

Lastly, the tools afforded by this approach to sense of place offer a way to study subjective, cultural, and relational dimensions of ecosystem services and the benefits they create, and to capture the fine-grained variations of ecosystem service delivery and access. These measures of sense of place can serve as indicators of changes in ecosystem service production as a result of stewardship interventions as well as social-ecological change.

Assessing outcomes also requires measures of how ecosystems affect human well-being (Smith et al. 2013), which should include both objective and subjective measures (Breslow et al. 2016). Sense of place offers measures that may be used as indicators of well-being at an individual and community level (Theodori 2001, Beckley et al. 2002, Lewicka 2011) or to quantify subjective wellbeing. For example, sense of place may be used to assess how ecosystem services contribute to well-being of different groups or to assess outcomes of a flood, market collapse, or rapid energy development (e.g., Jacquet and Stedman 2013, 2014). Our approach is grounded in an understanding of this well-being as both produced in a social context as well as rooted in a biophysical environment. Sense of place is thereby compatible with the SES understanding of ecosystems services as coproduced, i.e., that they emerge out of social-ecological interactions (Reyers et al. 2013, Anderson et al. 2015).

In addition to assessing change, sense of place is also useful for identifying priorities and cues for stewardship engagement in SES, for example, using tools such as described by Raymond et al. (2009). When combined with qualitative enquiries into place meanings, measures of place attachment can be particularly useful for assessing competing values and preferences and how they inform ecosystem management (Davenport and Anderson 2005) to guide how to move toward stewardship-based management.

\section{Stewardship and transformation in a changing world: future research questions}

Future integration of sense of place and SES will benefit from consideration of the broader interests of both fields. This includes strengths of sense of place such as the consideration of political influence as well as SES interests such as dynamic ecology, the interactions between temporal and spatial scales, and the interplay of rapid and incremental change. Engagement between these two research fields can open up or invigorate areas of inquiry in which the interests of both fields may be served.
The influence of chronic versus acute changes on sense of place: Social-ecological changes can vary in intensity and speed, which matters for how they are experienced and how people respond (Gunderson 2003). Research on transformation emphasizes rapid change and crisis as a window of opportunity and potential trigger for collective action (Folke et al. 2005). Gradual threats may allow for meanings and identities to be maintained through mitigative, incremental actions, which can impede the recognition of the need for radical change, or they can also result in slowly emerging conflicts over meanings and associated actions. In contrast, sudden threats may immediately challenge the viability of meanings and identity and may potentially trigger a reaction. Following disasters, the personal need to engage with the natural environment and to act to restore important place meanings may both create engagements with biophysical places (Tidball 2012, Stedman and Ingalls 2014) and rally a community to transformative action (Folke et al. 2005, Tidball and Krasny 2014). This can contribute to the understanding of what catalyzes and frames constructive collective action for transformation.

The contribution of place meanings to systems inertia or transformative change: Sense of place research emphasizes that meaning and attachment are dynamic and are in a constant state of creation and recreation (Stokowski 2002, Heise 2008). Moving beyond the effect of a static sense of place on individual behavior, future research should focus on mechanisms that link dynamic sense of place to the state or condition of an SES (and by implication, the resilience of the SES). In times of environmental or social change, place meanings often change slower than economic or environmental realities and can remain vital to local identity (Stedman 2002, Kyle et al. 2004, Lyon 2014). Meanings thereby may act as "slow" variables in the system, which can create a time lag that prevents timely action to respond to or prepare for changes. Simultaneously, relatively rapid biophysical change can make place meanings seem constant even when they are slowly changing (Keilty et al. 2016), extending the "shifting baseline" argument of Pauly (1995). This may lead to a social-ecological trap if meanings and attachments obfuscate ecological cues and people are not able to respond and adapt adequately or fast enough (Stedman 2016). In other situations, particularly in times of high social mobility and change, place meanings may act as a fast variable in a system as new actors precipitate a shift in meanings that has implications for ecosystem management.

Whose meanings are included and favored and why, and implications for SES: The academic traditions from which sense of place arose are concerned with understanding the power landscapes through which sense of place emerges. As places are partially socially constructed, their meanings can be socially contested and renegotiated (Pred 1984, Zukin 1991, Lyon 2014, Ingalls and Stedman 2016). Therefore, sense of place brings potential new tools and language for SES and resilience research to engage further with issues of "power to and power over" (Boonstra 2016) in collective action and negotiations of stewardship in SES. It is important that future research considers how and why certain place meanings and interests are promoted and reproduced through guided transformations toward sustainability (Leach et al. 2012) as well as in international decision making on sustainability issues such as climate change (Adger et al. 2011). Examining different place meanings provides one way to acknowledge and analyze the values and attitudes of multiple stakeholders and how their relative positions may influence the 
outcome of interventions in SES (Masterson 2016). Sense of place offers an approach to exploring power relationships for stewardship by analyzing top-down influences on people's place-based attitudes (e.g., Stokowski 2002, Bell and York 2010).

Ecologically informed meanings or "the ecology of sense of place": There is a need to go beyond a simplified and static view of nature or environmental problems that is displayed in much of the sense of place literature. A more coherent engagement with insights from resilience thinking, regarding, for example, cross-scale dynamics, functional diversity, and threshold effects (Folke 2006), would contribute to a fuller understanding of the biophysical elements of place. What are the roles of ecosystem qualities such as biodiversity and ecological integrity in forming and nurturing "sense of naturein-place"(Stedman and Ingalls 2014)? How does ecosystem change, incremental and rapid, affect sense of place (e.g., Tidball and Stedman 2013)? How do changing patterns of interactions with nature in places (e.g., through urbanization) alter meanings and attachment that may underpin stewardship? SES research also emphasizes the importance of learning in building resilience of SES. Can particular place meanings be associated with a deeper understanding of ecological dynamics and thereby provide a source of learning about how to manage that particular ecosystem or restore it from a degraded state (e.g., Enqvist et al. 2016)?

Scaling up stewardship behavior from individual to global: Sense of place literature is dominated by research occurring at relatively small scales (Lewicka 2011) and, as a consequence, proximity, direct experiences, and the length of exposure to the same physical space are factors that are often correlated with a strong sense of place. However, how do sense of place and sustainable behavior scale up? Can attachment to a local place promote stewardship at a more general level, in a kind of "rooted cosmopolitanism" (Chapin and Knapp 2015)? It has been suggested that "care may be a way to engage people in planetary stewardship by connecting their responses to what they notice in everyday life with their effect on larger environmental systems" (Nassauer 2011:321). When a personal experience of the whole biosphere is inaccessible, mediated experiences of the global ecological system may have a crucial role in defining a sense of the biosphere. The panarchy model in resilience thinking (Gunderson and Holling 2002) could provide a source of hypotheses about cross-scale dynamics of sense of place, which could be integrated with, e.g., studies of how attachment to neighborhood, state, country, and the globe are correlated with environmental attitudes (Devine-Wright et al. 2015).

\section{CONCLUSION}

Setting normative goals for the future and assessing their sustainability and the pathways that may lead toward them requires serious engagement with how values, behaviors, and emotions emerge from relationships with nature and ecosystem dynamics. To contribute to this work, we have investigated the connections between two complementary intellectual territories. It is a meeting of two pluralistic research domains. We do not present a symmetrical connection; rather, our effort has been to examine the extent to which sense of place insights from several decades of research can contribute to SES research and resilience thinking. In particular, we focus on an approach that views sense of place as created through social and ecological interactions.

Our approach clarifies sense of place constructs to deepen the understanding of the human variables that constrain or enable stewardship and transformative capacity. Specifically, these human value domains include the effect of cognition, emotion, and attitude on behavior. We show that for research on stewardship, sense of place literature can offer a language and robust conceptual building blocks that help unpack a person's relation to their physical and natural environment, explain the emergence of stewardship, and build a theoretical and methodological framework that better incorporates competing values and preferences in ecosystem governance and assessments. We also see promising engagement with sense of place concepts in studies of how people respond to change. A more systematic engagement with the subdimensions of attachment (identity and dependence) and meaning, as well as the use of instruments to assess these, will continue to improve the clarity, increase comparability, and further resolve discrepancies in findings. Crucially, we also propose that these tools may be usefully engaged in other research topics within SES: We offer these topics as a starting point where initial thinking has already occurred.

Our approach emphasizes place meanings as a key element of sense of place, complementing place attachment in predicting behavioral intent. By focusing on the meanings to which people are attached, we move beyond a normative view of sense of place as always positive for sustainability outcomes. We show that although values and cognitions are subjectively held and vary within a population and among characteristics of a place, this variation is systematic and can therefore be measured. With tools to identify how sense of place covaries with other system variables, our approach provides a way to assess how relation to place influences adaptive capacity, collaboration, and priorities for stewardship of SES.

Sustainability is about defining and working toward creating a tenable place for humanity to live. Whether place refers to one's backyard or the planet as a whole, understanding how people relate to places is key for sustainable development. One of the major challenges and opportunities is to develop integrated methods and indicators that could make these phenomena more tangible and measurable without neglecting the subjective, qualitative nature of sense of place. This, in turn, has direct implications for management of both small and vast SES that provide our home as humankind.

Responses to this article can be read online at: http://www.ecologyandsociety.org/issues/responses. $\mathrm{php} / 8872$

\footnotetext{
Acknowledgments:

We thank additional participants in the PhD course in Sense of place and resilience in social-ecological systems led by Richard Stedman at the Stockholm Resilience Centre during autumn 2013 (Emma Björkvik, Julie Goodness, Jamila Haider, Britt Stikvoort, and Viveca Mellegård) for assisting in the development of these ideas. We acknowledge a research grant from the Swedish Research Council (VR 2014-3394) and a core grant from MISTRA to the Stockholm Resilience Centre. Additionally, we acknowledge the following for supporting the collaboration: Cornell University College of Agriculture and Life Sciences supporting sabbatical
} 
leave, and Stockholm University, the Sweden-America Foundation, and $a$ C.F. Liljevachl J:or travel grant for supporting research visits to Cornell University. We also express our gratitude to Thomas Elmqvist for facilitating the collaboration and to Keith Tidball, Simon West, Erik Andersson, and three anonymous reviewers for helpful comments.

\section{LITERATURE CITED}

Adger, W. N., J. Barnett, K. Brown, N. Marshall, and K. O’Brien. 2013. Cultural dimensions of climate change impacts and adaptation. Nature Climate Change 3:112-117. http://dx.doi. org/10.1038/nclimate1666

Adger, W. N., J. Barnett, F. S. Chapin III, and H. Ellemor. 2011. This must be the place: underrepresentation of identity and meaning in climate change decision-making. Global Environmental Politics 11(2):1-25. http://dx.doi.org/10.1162/GLEP a 00051

Adger, W. N., S. Dessai, M. Goulden, M. Hulme, I. Lorenzoni, D. R. Nelson, L. O. Naess, J. Wolf, and A. Wreford. 2009. Are there social limits to adaptation to climate change? Climatic Change 93(3):335-354. http://dx.doi.org/10.1007/s10584-008-9520$\underline{z}$

Albrecht, G., G.-M. Sartore, L. Connor, N. Higginbotham, S. Freeman, B. Kelly, H. Stain, A. Tonna, and G. Pollard. 2007. Solastalgia: the distress caused by environmental change. Australasian Psychiatry 15(S1):S95-S98. http://dx.doi. org/10.1080/10398560701701288

Altman, I., and S. M. Low, editors. 1992. Place attachment. Springer, New York, New York, USA. http://dx.doi. org/10.1007/978-1-4684-8753-4

Amundsen, H. 2013. Place attachment as a driver of adaptation in coastal communities in northern Norway. Local Environment 20(3):257-276. http://dx.doi.org/10.1080/13549839.2013.838751

Andersson, E., S. Barthel, and K. Ahrné. 2007. Measuring socialecological dynamics behind the generation of ecosystem services. Ecological Applications 17(5):1267-1278. http://dx.doi. org/10.1890/06-1116.1

Andersson, E., M. Tengö, T. McPhearson, and P. Kremer. 2015. Cultural ecosystem services as a gateway for improving urban sustainability. Ecosystem Services 12:165-168. http://dx.doi. org/10.1016/j.ecoser.2014.08.002

Barthel, S., C. Crumley, and U. Svedin. 2013. Bio-cultural refugia - safeguarding diversity of practices for food security and biodiversity. Global Environmental Change 23(5):1142-1152. http://dx.doi.org/10.1016/j.gloenvcha.2013.05.001

Barthel, S., C. Folke, and J. Colding. 2010. Social-ecological memory in urban gardens-retaining the capacity for management of ecosystem services. Global Environmental Change 20(2):255-265. http://dx.doi.org/10.1016/j.gloenvcha.2010.01.001

Beckley, T., J. Parkins, and R. Stedman. 2002. Indicators of forestdependent community sustainability: the evolution of research. Forestry Chronicle 78(5):626-636. http://dx.doi.org/10.5558/ tfc78626-5

Beckley, T. M., R. C. Stedman, S. M. Wallace, and M. Ambard. 2007. Snapshots of what matters most: using resident-employed photography to articulate attachment to place. Society and Natural Resources 20(10):913-929. http://dx.doi.org/10.1080/08$\underline{941920701537007}$

Bell, S. E., and R. York. 2010. Community economic identity: the coal industry and ideology construction in West Virginia. Rural Sociology 75(1):111-143. http://dx.doi.org/10.1111/j.1549-0831.2009.00004. $\underline{x}$

Berkes, F., J. Colding, and C. Folke. 2000. Rediscovery of traditional ecological knowledge as adaptive management. Ecological Applications 10(5):1251-1262. http://dx.doi. org/10.1890/1051-0761(2000)010[1251:ROTEKA]2.0.CO;2

Berkes, F., J. Colding, and C. Folke, editors. 2003. Navigating social-ecological systems: building resilience for complexity and change. Cambridge University Press, Cambridge, UK. http://dx. doi.org/10.1017/cbo9780511541957

Berkes, F., and C. Folke, editors. 1998. Linking social and ecological systems: management practices and social mechanisms for building resilience. Cambridge University Press, Cambridge, UK.

Berkes, F., and H. Ross. 2013. Community resilience: toward an integrated approach. Society and Natural Resources 26(1):5-20. http://dx.doi.org/10.1080/08941920.2012.736605

Bonaiuto, M., G. Carrus, H. Martorella, and M. Bonnes. 2002. Local identity processes and environmental attitudes in land use changes: the case of natural protected areas. Journal of Economic Psychology 23(5):631-653. http://dx.doi.org/10.1016/S0167-4870 (02)00121-6

Boonstra, W. J. 2016. Conceptualizing power to study socialecological interactions. Ecology and Society 21(1):21. http://dx. doi.org/10.5751/es-07966-210121

Brehm, J. M., B. W. Eisenhauer, and R. C. Stedman. 2013. Environmental concern: examining the role of place meaning and place attachment. Society and Natural Resources 26(5):522-538. http://dx.doi.org/10.1080/08941920.2012.715726

Breslow, S. J., B. Sojka, R. Barnea, X. Basurto, C. Carothers, S. Charnley, S. Coulthard, N. Dolšak, J. Donatuto, C. GarcíaQuijano, C. C. Hicks, A. Levine, M. B. Mascia, K. Norman, M. Poe, T. Satterfield, K. St. Martin, and P. S. Levin. 2016. Conceptualizing and operationalizing human wellbeing for ecosystem assessment and management. Environmental Science and Policy 66:250-259. http://dx.doi.org/10.1016/j.envsci.2016.06.023

Brown, G., and C. Raymond. 2007. The relationship between place attachment and landscape values: toward mapping place attachment. Applied Geography 27(2):89-111. http://dx.doi. org/10.1016/j.apgeog.2006.11.002

Brown, K., S. O’Neill, and C. Fabricius. 2013. Social science understandings of transformation. Pages 100-106 in World social science report 2013: changing global environments. ISSC and UNESCO, Paris, France. http://dx.doi.org/10.1787/9789264203419-13$\underline{\text { en }}$

Butler, C. D., and W. Oluoch-Kosura. 2006. Linking future ecosystem services and future human well-being. Ecology and Society 11(1):30. http://dx.doi.org/10.5751/es-01602-110130 
Carpenter, S. R., H. A. Mooney, J. Agard, D. Capistrano, R. S. DeFries, S. Díaz, T. Dietz, A. K. Duraiappah, A. Oteng-Yeboah, H. M. Pereira, C. Perrings, W. V. Reid, J. Sarukhan, R. J. Scholes, and A. Whyte. 2009. Science for managing ecosystem services: beyond the Millennium Ecosystem Assessment. Proceedings of the National Academy of Sciences 106(5):1305-1312. http://dx. doi.org/10.1073/pnas.0808772106

Chan, K. M. A., P. Balvanera, K. Benessaiah, M. Chapman, S. Díaz, E. Gómez-Baggethun, R. Gould, N. Hannahs, K. Jax, S. Klain, G. W. Luck, B. Martín-López, B. Muraca, B. Norton, K. Ott, U. Pascual, T. Satterfield, M. Tadaki, J. Taggart, and N. Turner. 2016. Opinion: Why protect nature? Rethinking values and the environment. Proceedings of the National Academy of Sciences 113(6):1462-1465. http://dx.doi.org/10.1073/pnas.1525002113

Chan, K. M. A., A. D. Guerry, P. Balvanera, S. Klain, T. Satterfield, X. Basurto, A. Bostrom, R. Chuenpagdee, R. Gould, B. S. Halpern, N. Hannahs, J. Levine, B. Norton, M. Ruckelshaus, R. Russell, J. Tam, and U. Woodside. 2012. Where are cultural and social in ecosystem services? A framework for constructive engagement. BioScience 62(8):744-756. http://dx.doi.org/10.1525/ bio.2012.62.8.7

Chapin, F. S. III, S. R. Carpenter, G. P. Kofinas, C. Folke, N. Abel, W. C. Clark, P. Olsson, D. M. Stafford Smith, B. Walker, O. R. Young, F. Berkes, R. Biggs, J. M. Grove, R. L. Naylor, E. Pinkerton, W. Steffen, and F. J. Swanson. 2010. Ecosystem stewardship: sustainability strategies for a rapidly changing planet. Trends in Ecology and Evolution 25(4):241-249. http://dx. doi.org/10.1016/j.tree.2009.10.008

Chapin, F. S. III, and C. N. Knapp. 2015. Sense of place: a process for identifying and negotiating potentially contested visions of sustainability. Environmental Science and Policy 53(A):38-46. http://dx.doi.org/10.1016/j.envsci.2015.04.012

Chapin, F. S. III, A. F. Mark, R. A. Mitchell, and K. J. M. Dickinson. 2012. Design principles for social-ecological transformation toward sustainability: lessons from New Zealand sense of place. Ecosphere 3(5):1-22. http://dx.doi.org/10.1890/ es12-00009.1

Chapin, F. S. III, S. T. A. Pickett, M. E. Power, R. B. Jackson, D. M. Carter, and C. Duke. 2011. Earth stewardship: a strategy for social-ecological transformation to reverse planetary degradation. Journal of Environmental Studies and Sciences 1(1):44-53. http:// dx.doi.org/10.1007/s13412-011-0010-7

Clayton, S., P. Devine-Wright, P. C. Stern, L. Whitmarsh, A. Carrico, L. Steg, J. Swim, and M. Bonnes. 2015. Psychological research and global climate change. Nature Climate Change 5:640-646. http://dx.doi.org/10.1038/nclimate2622

Daniel, T. C., A. Muhar, A. Arnberger, O. Aznar, J. W. Boyd, K. M. A. Chan, R. Costanza, T. Elmqvist, C. G. Flint, P. H. Gobster, A. Grêt-Regamey, R. Lave, S. Muhar, M. Penker, R. G. Ribe, T. Schauppenlehner, T. Sikor, I. Soloviy, M. Spierenburg, K. Taczanowska, J. Tam, and A. von der Dunk. 2012. Contributions of cultural services to the ecosystem services agenda. Proceedings of the National Academy of Sciences 109(23):8812-8819. http:// dx.doi.org/10.1073/pnas.1114773109
Davenport, M. A., and D. H. Anderson. 2005. Getting from sense of place to place-based management: an interpretive investigation of place meanings and perceptions of landscape change. Society and Natural Resources 18(7):625-641. http://dx.doi. org/10.1080/08941920590959613

Davidson-Hunt, I. J., and F. Berkes. 2003. Nature and society through the lens of resilience: toward a human-in-ecosystem perspective. Pages 53-82 in F. Berkes, J. Colding, and C. Folke, editors. Navigating social-ecological systems: building resilience for complexity and change. Cambridge University Press, Cambridge, UK. https://doi.org/10.1017/CBO9780511541957.006

Daw, T., K. Brown, S. Rosendo, and R. Pomeroy. 2011. Applying the ecosystem services concept to poverty alleviation: the need to disaggregate human well-being. Environmental Conservation 38 (4):370-379. https://doi.org/10.1017/S0376892911000506

Devine-Wright, P. 2009. Rethinking NIMBYism: the role of place attachment and place identity in explaining place-protective action. Journal of Community and Applied Social Psychology 19 (6):426-441. http://dx.doi.org/10.1002/casp.1004

Devine-Wright, P., and Y. Howes. 2010. Disruption to place attachment and the protection of restorative environments: a wind energy case study. Journal of Environmental Psychology 30 (3):271-280. http://dx.doi.org/10.1016/j.jenvp.2010.01.008

Devine-Wright, P., J. Price, and Z. Leviston. 2015. My country or my planet? Exploring the influence of multiple place attachments and ideological beliefs upon climate change attitudes and opinions. Global Environmental Change 30:68-79. http://dx.doi. org/10.1016/j.gloenvcha.2014.10.012

Eakin, H., A. York, R. Aggarwal, S. Waters, J. Welch, C. Rubiños, S. Smith-Heisters, C. Bausch, and J. M. Anderies. 2016. Cognitive and institutional influences on farmers' adaptive capacity: insights into barriers and opportunities for transformative change in central Arizona. Regional Environmental Change 16 (3):801-814. http://dx.doi.org/10.1007/s10113-015-0789-y

Enqvist, J., M. Tengö, and Ö. Bodin. 2014. Citizen networks in the Garden City: protecting urban ecosystems in rapid urbanization. Landscape and Urban Planning 130:24-35. http:// dx.doi.org/10.1016/j.landurbplan.2014.06.007

Enqvist, J., M. Tengö, and W. J. Boonstra. 2016. Against the current: rewiring rigidity trap dynamics in urban water governance through civic engagement. Sustainability Science 11 (6):919-933. http://dx.doi.org/10.1007/s11625-016-0377-1

Ernstson, H., and S. Sörlin. 2009. Weaving protective stories: connective practices to articulate holistic values in the Stockholm National Urban Park. Environment and Planning 41 (6):1460-1479. http://dx.doi.org/10.1068/a40349

Farmer, J. R., D. Knapp, V. J. Meretsky, C. Chancellor, and B. C. Fischer. 2011. Motivations influencing the adoption of conservation easements. Conservation Biology 25(4):827-834. http://dx.doi.org/10.1111/j.1523-1739.2011.01686.x

Folke, C. 2006. Resilience: the emergence of a perspective for social-ecological systems analyses. Global Environmental Change 16(3):253-267. http://dx.doi.org/10.1016/j.gloenvcha.2006.04.002 
Folke, C., S. R. Carpenter, B. Walker, M. Scheffer, T. Chapin, and J. Rockström. 2010. Resilience thinking: integrating resilience, adaptability and transformability. Ecology and Society 15(4):20. [online] URL: http://www.ecologyandsociety.org/vol15/iss4/ $\underline{\operatorname{art} 20 /}$

Folke, C., J. Colding, and F. Berkes. 2003. Synthesis: building resilience and adaptive capacity in social-ecolgocial systems. Pages 352-387 in F. Berkes, J. Colding, and C. Folke, editors. Navigating social-ecological systems: building resilience for complexity and change. Cambridge University Press, Cambridge, UK. https://doi.org/10.1017/CBO9780511541957.020

Folke, C., T. Hahn, P. Olsson, and J. Norberg. 2005. Adaptive governance of social-ecological systems. Annual Review of Environment and Resources 30:441-473. http://dx.doi.org/10.1146/ annurev.energy.30.050504.144511

Folke, C., Å. Jansson, J. Rockström, P. Olsson, S. R. Carpenter, F. S. Chapin III, A.-S. Crépin, G. Daily, K. Danell, J. Ebbesson, T. Elmqvist, V. Galaz, F. Moberg, M. Nilsson, H. Österblom, E. Ostrom, Å. Persson, G. Peterson, S. Polasky, W. Steffen, B. Walker, and F. Westley. 2011. Reconnecting to the biosphere. Ambio 40:719-738. http://dx.doi.org/10.1007/s13280-011-0184-y

Fresque-Baxter, J. A., and D. Armitage. 2012. Place identity and climate change adaptation: a synthesis and framework for understanding. Wiley Interdisciplinary Reviews: Climate Change 3(3):251-266. http://dx.doi.org/10.1002/wcc.164

Freudenburg, W. R., S. Frickel, and R. Gramling. 1995. Beyond the nature/society divide: learning to think about a mountain. Sociological Forum 10(3):361-392. http://dx.doi.org/10.1007/ $\underline{\mathrm{BF} 02095827}$

Gifford, R. 2014. Environmental psychology matters. Annual Review of Psychology 65:541-579. http://dx.doi.org/10.1146/ annurev-psych-010213-115048

Greider, T., and L. Garkovich. 1994. Landscapes: the social construction of nature and the environment. Rural Sociology 59 (1):1-24. http://dx.doi.org/10.1111/j.1549-0831.1994.tb00519.x

Gunderson, L. H. 2003. Adaptive dancing: interactions between social resilience and ecological crises. Pages 33-52 in F. Berkes, J. Colding, and C. Folke, editors. Navigating social-ecological systems: building resilience for complexity and change. Cambridge University Press, Cambridge, UK. https://doi.org/10.1017/ CBO9780511541957.005

Gunderson, L. H., and C. S. Holling, editors. 2002. Panarchy: understanding transformations in human and natural systems. Island Press, Washington, D.C., USA.

Hausmann, A., R. Slotow, J. K. Burns, and E. Di Minin. 2016. The ecosystem service of sense of place: benefits for human wellbeing and biodiversity conservation. Environmental Conservation 43(2):117-127. http://dx.doi.org/10.1017/s0376892915000314

Heise, U. K. 2008. Sense of place and sense of planet: the environmental imagination of the global. Oxford University Press, Oxford, UK. http://dx.doi.org/10.1093/acprof:oso/97801953356$\underline{37.001 .0001}$

Hernández-Morcillo, M., T. Plieninger, and C. Bieling. 2013. An empirical review of cultural ecosystem service indicators.
Ecological Indicators 29:434-444. http://dx.doi.org/10.1016/j. ecolind.2013.01.013

Hidalgo, M. C., and B. Hernández. 2001. Place attachment: conceptual and empirical questions. Journal of Environmental Psychology 21(3):273-281. http://dx.doi.org/10.1006/jevp.2001.0221

Huber, M., and A. Arnberger. 2016. Opponents, waverers or supporters: the influence of place-attachment dimensions on local residents' acceptance of a planned biosphere reserve in Austria. Journal of Environmental Planning and Management 59 (9):1610-1628. http://dx.doi.org/10.1080/09640568.2015.1083415

Ingalls, M. L., and R. C. Stedman. 2016. The power problematic: exploring the uncertain terrains of political ecology and the resilience framework. Ecology and Society 21(1):6. http://dx.doi. org/10.5751/es-08124-210106

Jacquet, J. B., and R. C. Stedman. 2013. Perceived impacts from wind farm and natural gas development in northern Pennsylvania. Rural Sociology 78(4):450-472. http://dx.doi. org/10.1111/ruso.12022

Jacquet, J. B., and R. C. Stedman. 2014. The risk of socialpsychological disruption as an impact of energy development and environmental change. Journal of Environmental Planning and Management 57(9):1285-1304. http://dx.doi.org/10.1080/096405$\underline{68.2013 .820174}$

Jones, N. A., S. Shaw, H. Ross, K. Witt, and B. Pinner. 2016. The study of human values in understanding and managing socialecological systems. Ecology and Society 21(1):15. http://dx.doi. org/10.5751/es-07977-210115

Jorgensen, B. S., and R. C. Stedman. 2001. Sense of place as an attitude: lakeshore owners attitudes toward their properties. Journal of Environmental Psychology 21(3):233-248. http://dx.doi. org/10.1006/jevp.2001.0226

Kaltenborn, B. P. 1998. Effects of sense of place on responses to environmental impacts: a study among residents in Svalbard in the Norwegian high Arctic. Applied Geography 18(2):169-189. http://dx.doi.org/10.1016/s0143-6228(98)00002-2

Keilty, K., T. M. Beckley, and K. Sherren. 2016. Baselines of acceptability and generational change on the Mactaquac hydroelectric dam headpond (New Brunswick, Canada). Geoforum 75:234-248. http://dx.doi.org/10.1016/j.geoforum.2016.08.001

Kudryavtsev, A., R. C. Stedman, and M. E. Krasny. 2012. Sense of place in environmental education. Environmental Education Research 18(2):229-250. http://dx.doi.org/10.1080/13504622.2011.609615

Kyle, G., A. Graefe, R. Manning, and J. Bacon. 2004. Effects of place attachment on users' perceptions of social and environmental conditions in a natural setting. Journal of Environmental Psychology 24(2):213-225. http://dx.doi.org/10.1016/ j.jenvp.2003.12.006

Lalli, M. 1992. Urban-related identity: theory, measurement, and empirical findings. Journal of Environmental Psychology 12 (4):285-303. http://dx.doi.org/10.1016/S0272-4944(05)80078-7

Larson, S., D. M. De Freitas, and C. C. Hicks. 2013. Sense of place as a determinant of people's attitudes towards the environment: implications for natural resources management and 
planning in the Great Barrier Reef, Australia. Journal of Environmental Management 117:226-234. http://dx.doi.org/10.1016/ j.jenvman.2012.11.035

Leach, M., J. Rockström, P. Raskin, I. Scoones, A. C. Stirling, A. Smith, J. Thompson, E. Millstone, A. Ely, E. Arond, C. Folke, and P. Olsson. 2012. Transforming innovation for sustainability. Ecology and Society 17(2):11. http://dx.doi.org/10.5751/ es-04933-170211

Lewicka, M. 2011. Place attachment: How far have we come in the last 40 years? Journal of Environmental Psychology 31 (3):207-230. http://dx.doi.org/10.1016/j.jenvp.2010.10.001

Liu, J., T. Dietz, S. R. Carpenter, M. Alberti, C. Folke, E. Moran, A. N. Pell, P. Deadman, T. Kratz, J. Lubchenco, E. Ostrom, Z. Ouyang, W. Provencher, C. L. Redman, S. H. Schneider, and W. W. Taylor. 2007. Complexity of coupled human and natural systems. Science 317(5844):1513-1516. http://dx.doi.org/10.1126/ science. 1144004

Lyon, C. 2014. Place systems and social resilience: a framework for understanding place in social adaptation, resilience, and transformation. Society and Natural Resources 27(10):1009-1023. http://dx.doi.org/10.1080/08941920.2014.918228

Manzo, L. C. 2005. For better or worse: exploring multiple dimensions of place meaning. Journal of Environmental Psychology 25(1):67-86. http://dx.doi.org/10.1016/j.jenvp.2005.01.002

Marshall, N. A., S. Crimp, M. Curnock, M. Greenhill, G. Kuehne, Z. Leviston, and J. Ouzman. 2016. Some primary producers are more likely to transform their agricultural practices in response to climate change than others. Agriculture, Ecosystems and Environment 222:38-47. http://dx.doi.org/10.1016/j.agee.2016.02.004

Marshall, N. A., S. E. Park, W. N. Adger, K. Brown, and S. M. Howden. 2012. Transformational capacity and the influence of place and identity. Environmental Research Letters 7(3):034022. http://dx.doi.org/10.1088/1748-9326/7/3/034022

Marshall, N., and C. J. Stokes. 2014. Identifying thresholds and barriers to adaptation through measuring climate sensitivity and capacity to change in an Australian primary industry. Climatic Change 126(3):399-411. http://dx.doi.org/10.1007/s10584-014-1233$\underline{\mathrm{x}}$

Martín-López, B., I. Iniesta-Arandia, M. García-Llorente, I. Palomo, I. Casado-Arzuaga, D. García Del Amo, E. GómezBaggethun, E. Oteros-Rozas, I. Palacios-Agundez, B. Willaarts, J. A. González, F. Santos-Martín, M. Onaindia, C. LópezSantiago, and C. Montes. 2012. Uncovering ecosystem service bundles through social preferences. Plos One 7(6):e38970. http:// dx.doi.org/10.1371/journal.pone.0038970

Masterson, V. A. 2016. Sense of place and culture in the landscape of home: understanding social-ecological dynamics on the Wild Coast, South Africa. Dissertation. Stockholm Resilience Centre, Stockholm University, Sweden. [online] URL: http://su.divaportal.org $/ \mathrm{smash} / \mathrm{record}$.jsf?pid $=$ diva2 $\% 3 \mathrm{~A} 1044090 \&$ dswid $=-5802$

Meyfroidt, P. 2013. Environmental cognitions, land change, and social-ecological feedbacks: an overview. Journal of Land Use Science 8(3):341-367. http://dx.doi.org/10.1080/1747423x.2012.667452
Milcu, A. I., J. Hanspach, D. Abson, and J. Fischer. 2013. Cultural ecosystem services: a literature review and prospects for future research. Ecology and Society 18(3):44. http://dx.doi.org/10.5751/ es-05790-180344

Milcu, A. I., K. Sherren, J. Hanspach, D. Abson, and J. Fischer. 2014. Navigating conflicting landscape aspirations: application of a photo-based Q-method in Transylvania (central Romania). Land Use Policy 41:408-422. http://dx.doi.org/10.1016/j. landusepol.2014.06.019

Millennium Ecosystem Assessment. 2005. Ecosystems and human well-being: synthesis. Island Press, Washington, D.C., USA. [online] URL: http://www.millenniumassessment.org/documents/ document.356.aspx.pdf

Moore, R. L., and A. R. Graefe. 1994. Attachments to recreation settings: the case of rail-trail users. Leisure Sciences 16(1):17-31. http://dx.doi.org/10.1080/01490409409513214

Nassauer, J. I. 2011. Care and stewardship: from home to planet. Landscape and Urban Planning 100(4):321-323. http://dx.doi. org/10.1016/j.landurbplan.2011.02.022

Olsson, P., and C. Folke. 2001. Local ecological knowledge and institutional dynamics for ecosystem management: a study of Lake Racken watershed, Sweden. Ecosystems 4(2):85-104. http:// dx.doi.org/10.1007/s100210000061

Pauly, D. 1995. Anecdotes and the shifting baseline syndrome of fisheries. Trends in Ecology and Evolution 10(10):430. http://dx. doi.org/10.1016/s0169-5347(00)89171-5

Plieninger, T., S. Dijks, E. Oteros-Rozas, and C. Bieling. 2013. Assessing, mapping, and quantifying cultural ecosystem services at community level. Land Use Policy 33:118-129. http://dx.doi. org/10.1016/j.landusepol.2012.12.013

Potschin, M., and R. Haines-Young. 2013. Landscapes, sustainability and the place-based analysis of ecosystem services. Landscape Ecology 28(6):1053-1065. http://dx.doi.org/10.1007/ s10980-012-9756-X

Pred, A. 1984. Place as historically contingent process: structuration and the time-geography of becoming places. Annals of the Association of American Geographers 74(2):279-297. http:// dx.doi.org/10.1111/j.1467-8306.1984.tb01453.x

Pretty, G. H., H. M. Chipuer, and P. Bramston 2003. Sense of place amongst adolescents and adults in two rural Australian towns: the discriminating features of place attachment, sense of community and place dependence in relation to place identity. Journal of Environmental Psychology 23(3):273-287. http://dx.doi. org/10.1016/s0272-4944(02)00079-8

Pröpper, M., and F. Haupts. 2014. The culturality of ecosystem services. Emphasizing process and transformation. Ecological Economics 108:28-35. http://dx.doi.org/10.1016/j.ecolecon.2014.09.023

Proshansky, H. M. 1978. The city and self-identity. Environment and Behavior 10(2):147-169. http://dx.doi.org/10.1177/0013916578102002

Quinn, T. 2014. The role of place attachment in proactive and reactive adaptation to flood risk. Dissertation. University of East Anglia, Norwich, UK. [online] URL: https://ueaeprints.uea.ac. $\underline{\mathrm{uk} / 49467 /}$ 
Raudsepp-Hearne, C., G. D. Peterson, M. Tengö, E. M. Bennett, T. Holland, K. Benessaiah, G. K. MacDonald, and L. Pfeifer. 2010. Untangling the environmentalist's paradox: Why is human well-being increasing as ecosystem services degrade? BioScience 60(8):576-589. http://dx.doi.org/10.1525/bio.2010.60.8.4

Raymond, C. M., G. Brown, and G. M. Robinson. 2011. The influence of place attachment, and moral and normative concerns on the conservation of native vegetation: a test of two behavioural models. Journal of Environmental Psychology 31(4):323-335. http://dx.doi.org/10.1016/j.jenvp.2011.08.006

Raymond, C. M., B. A. Bryan, D. Hatton MacDonald, A. Cast, S. Strathearn, A. Grandgirard, and T. Kalivas. 2009. Mapping community values for natural capital and ecosystem services. Ecological Economics 68(5):1301-1315. http://dx.doi.org/10.1016/ j.ecolecon.2008.12.006

Raymond, C. M., G. G. Singh, K. Benessaiah, J. R. Bernhardt, J. Levine, H. Nelson, N. J. Turner, B. Norton, J. Tam, and K. M. A. Chan. 2013. Ecosystem services and beyond: using multiple metaphors to understand human-environment relationships. BioScience 63(7):536-546.

Relph, E. 1976. Place and placelessness. Pion, London, UK.

Reyers, B., R. Biggs, G. S. Cumming, T. Elmqvist, A. P. Hejnowicz, and S. Polasky. 2013. Getting the measure of ecosystem services: a social-ecological approach. Frontiers in Ecology and the Environment 11(5):268-273. http://dx.doi.org/10.1890/120144

Rickard, L. N., and R. C. Stedman. 2015. From ranger talks to radio stations: the role of communication in sense of place. Journal of Leisure Research 47(1):15-33.

Russ, A., S. J. Peters, M. E. Krasny, and R. C. Stedman. 2015. Development of ecological place meaning in New York City. Journal of Environmental Education 46(2):73-93. http://dx.doi. org/10.1080/00958964.2014.999743

Russell, R., A. D. Guerry, P. Balvanera, R. K. Gould, X. Basurto, K. M. A. Chan, S. Klain, J. Levine, and J. Tam. 2013. Humans and nature: how knowing and experiencing nature affect wellbeing. Annual Review of Environment and Resources 38 (1):473-502. http://dx.doi.org/10.1146/annurev-environ-012312-110838

Sack, R. D. 1997. Homo geographicus: a framework for action, awareness, and moral concern. Johns Hopkins University Press, Baltimore, Maryland, USA.

Sampson, K., and C. Goodrich. 2005. "We're coasters, why should we move?": community identity, place attachment and forestry closure in rural New Zealand. Sites 2(1):24-49. http://dx.doi. org/10.11157/sites-vol2iss1id55

Scannell, L., and R. Gifford. 2010. The relations between natural and civic place attachment and pro-environmental behavior. Journal of Environmental Psychology 30(3):289-297. http://dx.doi. org/10.1016/j.jenvp.2010.01.010

Seamon, D. 2000. A way of seeing people and place: phenomenology in envrionment-behavior research. Page 157-178 in S. Wapner, J. Demick, C. T. Yamamoto, and H. Minami, editors. Theoretical perspectives in environment-behavior research. Springer, New York, New York, USA. http://dx.doi. org/10.1007/978-1-4615-4701-3_13
Shamai, S. 1991. Sense of place: an empirical measurement. Geoforum 22(3):347-358. http://dx.doi.org/10.1016/0016-7185 (91)90017-k

Smith, L. M., J. L. Case, H. M. Smith, L. C. Harwell, and J. K. Summers. 2013. Relating ecoystem services to domains of human well-being: foundation for a U.S. index. Ecological Indicators 28:79-90. http://dx.doi.org/10.1016/j.ecolind.2012.02.032

Stedman, R. C. 1999. Sense of place as indicator of community sustainability. Forestry Chronicle 75(5):765-770. http://dx.doi. org/10.5558/tfc $75765-5$

Stedman, R. C. 2002. Toward a psychology of place: predicting behavior from place-based cognitions, attitude, and identity. Environment and Behavior 34(5):561-581. http://dx.doi. org/10.1177/0013916502034005001

Stedman, R. C. $2003 a$. Is it really just a social construction?: The contribution of the physical environment to sense of place. Society and Natural Resources 16(8):671-685.

Stedman, R. C. 2003b. Sense of place and forest science: toward a program of quantitative research. Forest Science 49(6):822-829.

Stedman, R. C. 2006. Understanding place attachment among second home owners. American Behavioral Scientist 50 (2):187-205. http://dx.doi.org/10.1177/0002764206290633

Stedman, R. C. 2008. What do we "mean" by place meanings? Implications of place meanings for managers and practitioners. Pages 71-82 in L. E. Kruger, T. E. Hall, and M. C. Stiefel, editors. Understanding concepts of place in recreation research and management. General Technical Report PNW-GTR-744. U.S. Department of Agriculture Forest Service Pacific Northwest Research Station, Portland, Oregon, USA. [online] URL: https:// www.treesearch.fs.fed.us/pubs/29924

Stedman, R. C. 2016. Subjectivity and social-ecological systems: a rigidity trap (and sense of place as a way out). Sustainability Science 11(6):891-901. http://dx.doi.org/10.1007/s11625-016-0388y

Stedman, R. C., and T. M. Beckley. 2007. "If we knew what it was we were doing, it would not be called research, would it?" Society and Natural Resources 20(10):939-943.

Stedman, R. C., and R. B. Hammer. 2006. Environmental perception in a rapidly growing, amenity-rich region: the effects of lakeshore development on perceived water quality in Vilas County, Wisconsin. Society and Natural Resources 19(2):137-151. http://dx.doi.org/10.1080/08941920500394733

Stedman, R. C., and M. Ingalls. 2014. Topophilia, biophilia and greening in the red zone. Pages 129-144 in K. G. Tidball and M. E. Krasny, editors. Greening in the red zon: disaster, resilience and community greening. Springer, Dordrecht, The Netherlands. http://dx.doi.org/10.1007/978-90-481-9947-1 10

Stokols, D., and S. A. Shumaker. 1981. People in places: a transactional view of settings. Pages 441-488 in J. H. Harvey, editor. Cognition, social behavior, and the environment. Lawrence Erlbaum, Hillsdale, New Jersey, USA.

Stokowski, P. A. 2002. Languages of place and discourses of power: constructing new senses of place. Journal of Leisure Research 34(4):368-382. 
Summers, J. K., L. M. Smith, J. L. Case, and R. A. Linthurst. 2012. A review of the elements of human well-being with an emphasis on the contribution of ecosystem services. Ambio 41 (4):327-340. http://dx.doi.org/10.1007/s13280-012-0256-7

Tengö, M., and J. von Heland. 2011. Adaptive capacity of local indigenous institutions: the case of the taboo forests of southern Madagascar. Pages 37-74 in E. Boyd and C. Folke, editors. Adapting institutions: governance, complexity and socialecological resilience. Cambridge University Press, Cambridge, UK. https://doi.org/10.1017/CBO9781139017237.006

Theodori, G. L. 2001. Examining the effects of community satisfaction and attachment on individual well-being. Rural Sociology 66(4):618-628. http://dx.doi.org/10.1111/j.1549-0831.2001. tb00087.x

Tidball, K. G. 2012. Urgent biophilia: human-nature interactions and biological attractions in disaster resilience. Ecology and Society 17(2):5. http://dx.doi.org/10.5751/es-04596-170205

Tidball, K. G., and M. Krasny. 2014. Greening in the red zone: disaster, resilience, and community greening. Springer, Dordrecht, The Netherlands. http://dx.doi.org/10.1007/978-90-481-9947-1

Tidball, K., and R. Stedman. 2013. Positive dependency and virtuous cycles: from resource dependence to resilience in urban social-ecological systems. Ecological Economics 86:292-299. http://dx.doi.org/10.1016/j.ecolecon.2012.10.004

Trentelman, C. K. 2009. Place attachment and community attachment: a primer grounded in the lived experience of a community sociologist. Society and Natural Resources 22 (3):191-210. http://dx.doi.org/10.1080/08941920802191712

Tuan, Y.-F. 1977. Space and place: the perspective of experience. University of Minnesota Press, Minneapolis, Minnesota, USA.

United Nations. 2014. Open Working Group proposal for sustainable development goals. A/68/970. Open Working Group of the General Assembly on Sustainable Development Goals, United Nations, New York, New York, USA. [online] URL: https://sustainabledevelopment.un.org/content/documents/1579SDGs $\%$ 20Proposal.pdf

von Heland, J., and C. Folke. 2014. A social contract with the ancestors-culture and ecosystem services in southern Madagascar. Global Environmental Change 24:251-264. http://dx. doi.org/10.1016/j.gloenvcha.2013.11.003

Vorkinn, M., and H. Riese. 2001. Environmental concern in a local context: the significance of place attachment. Environment and Behavior 33(2):249-263. http://dx.doi.org/10.1177/00139160$\underline{121972972}$

Walker, B., C. S. Holling, S. R. Carpenter, and A. Kinzig. 2004. Resilience, adaptability and transformability in social-ecological systems. Ecology and Society 9(2):5. http://dx.doi.org/10.5751/ es-00650-090205

Westley, F., P. Olsson, C. Folke, T. Homer-Dixon, H. Vredenburg, D. Loorbach, J. Thompson, M. Nilsson, E. Lambin, J. Sendzimir, B. Banerjee, V. Galaz, and S. van der Leeuw. 2011. Tipping toward sustainability: emerging pathways of transformation. Ambio 40 (7):762-780. http://dx.doi.org/10.1007/s13280-011-0186-9
Wilbanks, T. J. 2015. Putting "place" in a multiscale context: perspectives from the sustainability sciences. Environmental Science and Policy 53(A):70-79. http://dx.doi.org/10.1016/j. envsci.2015.04.009

Williams, D. R., and M. E. Patterson. 2007. Snapshots of what, exactly? A comment on methodological experimentation and conceptual foundations in place research. Society and Natural Resources 20(10):931-937. http://dx.doi.org/10.1080/08941920701537015

Williams, D. R., and J. W. Roggenbuck. 1989. Measuring place attachment: some preliminary results. Page 32 in L. H. McAvoy and D. Howard, editors. Abstracts of the 1989 Leisure Research Symposium. National Recreation and Park Association, Arlington, Virginia, USA.

Yung, L., W. A. Freimund, and J. M. Belsky. 2003. The politics of place: understanding meaning, common ground, and political difference on the Rocky Mountain front. Forest Science 49 (6):855-866.

Zukin, S. 1991. Landscapes of power: from Detroit to Disney World. University of California Press, Berkeley, California, USA.

Zylstra, M. J., A. T. Knight, K. J. Esler, and L. L. L. Le Grange. 2014. Connectedness as a core conservation concern: an interdisciplinary review of theory and a call for practice. Springer Science Reviews 2(1):119-143. http://dx.doi.org/10.1007/s40362-014-0021-3 